\title{
ÉTICA: QUESTÕES E PROBLEMAS CONTEMPORÂNEOS *
}

\author{
Alcira B. Bonilla \\ Universidad de Buenos Aires/CONICET
}

\begin{abstract}
Moral philosophy or ethics holds nowadays the rank of "First Philosophy". In this article I try to reflect the state of art in this field. The text is divided in four sections: "Clearing the language: moral and ethics", "The phenomenon of the morality", "The technical use of the words by current thinkers", and "'Applied Ethics' and the contemporary 'Ethical turn"'.
\end{abstract}

Key words: Ethics; moral; morality; applied ethics; ethical turn.

Resumo: A filosofia moral ou a ética filosófica deve ser considerada, hoje em dia, como "a filosofia primeira". Este artigo procura refletir o status questionis neste campo. O texto dividese em quatro parágrafos: aclarando a linguagem moral(is) e ética(s), o fenômeno da moralidade, o uso técnico dos termos no pensamento atual e a 'ética aplicada'e o 'giro ético' contemporâneo.

Palavras-chave: Ética; moral; moralidade; ética aplicada; giro ético.

Sem desdenhar as contribuições a ética teórica, por parte de disciplinas como a psicologia, antropologia, a historiografia, a sociologia, a teologia e/ou a psicanálise, esta colaboração se centra em indagações sobre filosofia moral ou ética filosófica. Esta escolha responde às mudanças de nosso tempo. Por isso, tais trabalhos adquiriram um caráter central no pensamento atual, a ponto de obrigar a redesenhar o mapa da filosofia atual. Victoria Camps retrata a situação através da contundente locução:

*Tradução de Jovino Pizzi. 
A segunda metade do século $\mathrm{XX}$ assistiu à evidente recuperação da teoria ética, até o ponto de que não é insensato nem errôneo afirmar que, hoje em dia, a "filosofia primeira" já não é metafísica ou teoria do conhecimento, como aconteceu na modernidade, mas filosofia moral (Camps; Guariglia; Salmerón, 1992: 19).

Essa caracterização da ética como "filosofia primeira" deve ser considerada aqui meramente como descrição do estado atual da disciplina (e não no sentido mais forte de Emmanuel Levinas). ${ }^{2}$ Se a este ressurgimento da ética se acrescenta o fenômeno do aparecimento, desenvolvimento e auge da denominada "ética aplicada" (que também produziu uma revisão da ética teórica tradicional), é possível falar, então, com propriedade de um "giro ético" da pesquisa, docência e de diversas dimensões das práticas sociais contemporâneas vinculadas com as normas e valores que caracterizam a convivência.

\section{Aclarando a linguagem: moral(is) e ética(s)}

Embora os termos "ética" e "moral" reverterem-se, muitas vezes, em sinônimos, não é nada surpreendente partir de uma reflexão sobre seu emprego nos diversos contextos. Em espanhol, esses usos estão registrados pelo Dicionário da Real Academia Espanhola (DRAE). Pari passu isso torna obrigatório um estudo mais apurado dos aspectos etimológicos e na revisão das diversas acepções técnico-filosóficas, tanto em autores clássicos como nos contemporâneos. Por isso, não se trata de meros "jogos de palavras", pois em cada acepção está implicada com tradições lingüísticas, filosóficas e profissionais e, inclusive, confusões ou obscurantismos de sentido.

A informação do Dicionário Real da Academia Espanhola (DRAE) mostra-se bastante desestimuladora, embora remeta à conflitividade do tema. Isso pode ser demonstrado através de, por exemplo, três termos: "ética", "ético", “-a” e "moral”, deixando de lado outros importantes vocábulos concernentes à constelação de "moral” (moralidade, moralista, moralização, morali-

\footnotetext{
2 E. Levinas buscou uma desarticulação da ontologia contemporânea, concebendo a ética como "filosofia primeira"; sua postura poderia ser caracterizada como "transcedentalismo ético", claramente exposta em Totalité et infini (Levinas, 1961).
} 
zador, moralizar, moralmente, imoral, amoral). a) Na primeira definição de Ética, o DRAE indica sua proveniência do latim aethica, derivado do substantivo grego ethiké, que, por sua vez, procedente da forma feminina do adjetivo ethikós. A definição da única acepção remete a um emprego técnico filosófico, pois "parte da filosofia que trata da moral e das obrigações do homem” (DRAE, 2000: 924). a) Em segundo lugar, o adjetivo "ético", “-ca” se destaca da origem greco-latina (aethicus, derivado de ethikós, e esse de éthos costume) e se registra o sentido para o adjetivo de "pertencente à ética" e, ao mesmo tempo, salienta outra acepção caracterizada através de sua substantivação masculina: "Pessoa que estuda ou ensina moral" (DRAE, 2000: 924). Com essas definições, pouco pode fazer um professor de ética ou um pesquisador, salvo que se dedique a completá-las com a ressalva histórico-literária e dos diversos empregos atuais (por exemplo, o da palavra "ética" na expressão "ética profissional"). c) Por fim, o vocábulo moral, sem insistir em questões etimológicas, evidencia quatro acepções do emprego adjetivo e quatro como substantivos: "Pertencente ou relativo às ações ou caráter das pessoas a partir do ponto de vista da bondade ou malicia". "Que não pertence ao campo dos sentidos, por ser da apreciação do entendimento ou da consciência. Prova, certeza MORAL”. Diante disso, há a um número regular de substantivos, tipificado pelo adjetivo, tratados nas entradas correspondentes: evidência, figura, filosofia, impossibilidade, livro, teologia, verdade e virtude moral. A quarta acepção indica: "Que não concerne à ordem jurídica, mas ao foro interno ou ao respeito humano", com um exemplo esclarecedor: "Embora o pagamento não fosse exigível, tinha a obrigação MORAL de fazê-lo". Essa acepção apresenta quatro substantivos: "ciência que trata do bem em geral e das ações humanas na ordem da sua bondade ou malicia"; "conjunto de faculdades do espírito, por contraposição a físico"; "ânimo, determinação" e "estado de ânimo, individual ou coletivo. Em relação às tropas ou ao esporte, se refere ao espírito ou à confiança na vitória” (DRAE, 2000, 1400).

Para o esclarecimento etimológico desses termos, existem duas vias de acesso. Por um lado, a derivação do adjetivo grego mediante o qual se designa uma disciplina particular da filosofia denominada ethikón, através da oposição às physikón e dialektikón (as outras duas partes que a completam, conforme a divisão helenística usual que sistematiza o uso clássico). Esta menção aparece, por exemplo, no "Proêmio" 18, do conhecido texto de Diógenes Laércio (Diógenes Laertius, 1959), demonstrando que o uso técnico em grego foi primeiramente adjetivo; assim, filósofos como Platão e Aristóteles o 
empregaram com freqüência. Embora na Política $(4,11,3)$ a forma substantivada apareça no plural tà ethikà, Aristóteles reconhece este objeto de sua investigação (a "ciência ética") como uma "certa" (tis) disciplina "política" e sublinhe aspectos etimológicos que remetem a uma constelação de sentido das palavras gregas, derivadas do radical indo-europeu *swe (que designa ou hábito em tanto "caráter distintivo e maneira de ser individual"). As indicações do artigo Moeurs, de Alain Pons, indica que *swe se encontra no substantivo neutro éthos, ous (hábito, costume, uso) e no substantivo ethos, -ous que, empregado no plural, significa a morada familiar, o lar, e, no singular, o caráter habitual: ${ }^{3}$

Com freqüência, seu emprego se aproxima ao de éthos, mas corresponde mais bem à manifestação do habitual de um indivíduo ou de uma coletividade, a seu "caráter". Isso deriva o adjetivo ethikós e esse é o seu sentido em Aristóteles. Em grego, a palavra éthnos se origina também da mesma raiz e, de modo sugestivo, designa qualquer classe de seres de origem ou de condição comum, por conseguinte, raça, povo, nação, tribo (Pons, 1996: 977).

Embora não se conheça propriamente a etimologia de mos, moris, palavra que equivale à maneira de se comportar e ao modo de agir, não determinado pela lei, mas pelo uso, ela frequentemente designa "costume" e "caráter" (em geral, no plural: mores). Desta última acepção provém moralis, termo criado por Cícero $(F a t, 1,1)$, que traduz o ethikós grego, e jamais do latim, moralitas (Ernout; Meillet, 1959: 415-416). É importante recordar que, para os antigos romanos, o mos maiorum, ou seja, o conjunto de costumes dos dias passados, possuíam uma força constritiva maior que a da lex. ${ }^{4}$

Quanto se passa ao emprego atual, além do sentido técnico geral da ética como disciplina filosófica, costuma-se empregar o termo "ética" como substantivo, para designar a conduta moral da qual se é capaz de dar conta. Desse modo, como adjetivo "ético, -a", estar-se-ia mostrando a qualidade de

${ }^{3}$ Aristóteles (Ética Nicomáquea, II, 1, 1003 a) afirma, com referência à classe ética das virtudes: "a ética (ethiké), em mudança, procede do costume (éthos), como indica o nome, o qual varia ligeiramente do de costume". Em relação a isso, pode-se consultar José L. Aranguren, que trata do "princípio etimológico" (Aranguren, 1968: capítulo II). Assim, imaginar a "ética" como derivada de "ethos", significa também pensá-la como a que determina a "morada" do homem, o espaço de convivência que ele constrói.

${ }^{4}$ "Família, exército e estado se mantiveram, durante séculos, graças ao código normativo das 'mores"' (Bilbeny, 1992: 15). 
determinado ato ou norma moral. Derivado desse sentido, ele denota respeito por um código profissional de ética (Cortina; Martínez, 1997: 21). De tal uso, muito freqüente, pode extrair-se a seguinte conclusão:

Poderíamos dizer, portanto, que há muitas "morais" e não menos éticas ou "filosofias morais", mas apenas uma só ética ou conduta consistente em uma forma razoada - capaz de dar conta de si mesma - de ser moral. Enquanto que a moral tende a ser particular, pela concreção de seus objetos, a ética tende a ser universal, pela abstração de seus princípios (Bilbeny, 1992: 15).

Essa afirmação, com forte cunho universalista, opõe-se, por princípio, a qualquer forma de relativismo (e, nesse sentido, aposta em formas de convivência planetárias), expondo, no entanto, um etnocentrismo disfarçado. Como se observou em diversos episódios de genocídios, de opressão colonial e de ultraje dos imigrantes com traços fenótipos não ocidentais, que invocaram tal universalismo, ele não deixa espaço, teórico ou prático, a outras formas (não européias, em muitos casos) de entender a racionalidade e a universalidade. Em vista da pluralidade de pessoas e racionalidades, que habitam especialmente as megalópoles contemporâneas, bem como os conflitos de convivência e de entendimento mútuo gerados constantemente, é possível matizar, atualmente, este universalismo a priori com modos mais horizontais de entendê-lo. Trata-se do perigo etnólogo-falocêntrico da cultura ocidental, como salienta, por exemplo, a proposta da filosofia intercultural contemporânea da Escola de Aachen, desenvolvida particularmente por Raúl FornetBetancourt e Josef Estermann. Eles se definem por um modo polilógico de construção do universalismo a partir dois contextos (Fornet-Betancourt, 1992, 2002, 2003; Estermann, 1998).

Com relação aos termos "moral" e "moralidade", a questão é mais complexa, como o evidência as acepções registradas pelo DRAE. Adela Cortina e Emilio Martínez oferecem uma sistematização didática adequada dos usos de moral e de moralidade, sintetizada a seguir.

Os usos de "moral" como substantivo pode ser aclarado do seguinte modo: a) modelo de conduta socialmente estabelecido em uma sociedade concreta; b) conjunto de convicções morais pessoais; c) tratados sistemáticos sobre as questões morais, os quais compreendem doutrinas morais e teorias 
éticas; d) disposição de ânimo produzido pelo caráter e atitudes adquiridos por uma pessoa ou grupo; e) dimensão da vida humana através da qual nos vemos obrigados a tomar decisões e a dar-lhe razão. Entre os usos de "moral" como adjetivo, destacam-se as acepções vinculadas com a oposição moral/imoral (sinônimo de moralmente correto ou incorreto, em cujo caso se pressuporia a existência de um código ou padrão que permita formular o juízo correspondente) e as acepções vinculadas com a oposição moral/amoral (termos meramente descritivos, enquanto "expressam que uma conduta é, ou não, suscetível de qualificação moral, porque reúne, ou não, os requisitos indispensáveis para ser colocada em relação com as orientações morais normas, valores, conselhos, etc.)”.

Em relação aos usos de "moralidade", temos: a) sinônimo de "moral" no sentido de uma concepção moral concreta; b) sinônimo do 'moral': uma dimensão da vida humana identificável entre outras e não reduzível a nenhuma outra; c) "na contraposição filosófica de raiz hegeliana entre 'moralidade' e 'eticidade” (Cortina; Martínez, 1997: 18 e 20). ${ }^{5}$ Em termos gerais, interessam à ética filosófica, de modo especial, os usos A e B do termo "moralidade”. Embora os antropólogos, os sociólogos e os psicólogos pesquisaram o fenômeno moral a partir de suas respectivas matérias, determinar em que ele consiste resulta em um problema sumamente importante para a ética. Uma das características mais importantes do fenômeno moral é o da normatividade. No entanto, entendendo "norma" no sentido prescritivo amplo, é possível indicar o troço característico de "obrigatoriedade" tanto para as normas morais, como para as legais ou jurídicas, religiosas, sociais, técnicas, etc.

\section{0 fenômeno da moralidade}

Antes de passar ao estudo de alguns exemplos contemporâneos do uso técnico-filosófico dos termos "ética" e "moral” e de sua possível distinção no contexto de teorias particulares, parece útil uma referência ao fenômeno da moralidade, antecedente à obviedade de toda reflexão sobre ele. A análise da

\footnotetext{
${ }^{5}$ Basta recordar que Moralität e Sittlichkeit ("eticidade") nos Princípios da Filosofia do Direito (Hegel, 1975) indicam dois momentos do "Espírito objetivo" posteriores ao do "direito abstrato"; o momento da "moralidade", isto é, da moralidade como vontade subjetiva, tal como ela se manifesta no indivíduo, deve ser superado e, por conseguinte, não abandonado, mas subordinado ao da vida ética, na qual ou indivíduo já não existe como momento abstrato. Por isso, sua subjetividade se realiza na objetividade de um mundo.
} 
experiência moral, obsequiada pelas diversas ciências sociais, oferece a base empírica para ou desenvolvimento teórico da ética ou da filosofia moral. Isso não significa nenhuma incumbência de "falácia naturalista", mas a simples constatação de um modo de ser permanente da condição humana. Além disso, trata-se de uma prevenção a respeito da necessidade de não esquecer os contextos nos quais, originariamente, as diversas teorias éticas foram sendo elaboradas. $^{6}$

Ao considerar a moralidade como uma instituição humana, é possível destacar dela, os elementos seguintes: a) nossas práticas morais, ao estilo dos castigos e das recompensas; b) nossas emoções e sentimentos morais, tais como o agradecimento, a culpa e outros; c) nossos pensamentos e juízos morais (Platts, 1997: 7). Todas as sociedades manifestam comportamentos prático-morais, a ponto de serem vistos como inerentes a elas; as morais generalizam tais comportamentos. Por essa razão, Niklas Luhmann define a moral nos termos seguintes:

A moral é uma generalização simbólica que reduz a total complexidade reflexiva das relações alter/ego, as quais são duplamente contingentes a expressões de estima, e que abre, devido a esta generalização, 1) um espaço livre para os condicionamentos e 2) a possibilidade de reconstruir a complexidade mediante o esquema binário estima/desestima (Luhmann, 1998: 220).

Como já foi insinuado anteriormente, isso não significa que as expressões concretas do fato moral sejam homogêneas em todas as sociedades. Sua variabilidade é enorme. Por isso, elas são partes do processo de autoprodução multiforme do homem. Em uma tentativa de classificação, foi salientado, por exemplo, a distinção entre culturas da "vergonha" (shame cultures), entendendo-a como o sentimento reativo ao juízo adverso das demais frente a um comportamento considerado nocivo, e culturas da "culpa" (guilt cultures), nas quais a crítica alheia é secundária. Por isso, a reprovação ou a aprovação do comportamento provém do foro interno. A antropóloga norteamericana Ruth Benedict realizou uma eficaz e célebre distinção no seu estu-

${ }^{6}$ Muito pouco poderia ser entendido da ética kantiana, por exemplo, se esquecêssemos 0 âmbito pietista e de livre exame da Bíblia, no qual o filósofo passou seus primeiros anos, assim como o contexto político em que ele viveu. 
do sobre a cultura japonesa de 1946, cuja diferença "enigmática" com a norte-americana se tornou, ao finalizar a Segunda Guerra Mundial, um assunto de Estado (Benedict, 1975: 200-203). Aproximando-se ao campo da ética ocidental propriamente dita, E. R. Dodds se apropria da distinção antropológica no esforço por tornar compreensível a moral grega arcaica, tal como os textos homéricos a expõem. Ele também salienta suas diferenças com os desenvolvimentos posteriores da ética grega, sem esquecer a influência que exerceu também sobre o pensamento ocidental outra das fontes (antiga e poderosa) da cultura da culpa - a bíblica -ambas determinantes do mundo moderno e, no entanto, influentes (Dodds, 1960: capítulos 1-2).

\section{0 uso técnico dos termos no pensamento atual}

Alguns autores se dão por satisfeitos com a distinção técnica mais ampla em que já foi tratada. Assim Carlos Cullen, que reconhece a complexidade do campo problemático da ética filosófica, parte do pressuposto da distinção entre ética e moral, comentando sua "relativa aceitação", em nossos dias, por parte da comunidade de especialistas:

A distinção entre ética - como disciplina filosófica (pelo mesmo racional e crítica) - e moral - como o conjunto de valores, normas, princípios que regem as ações dos homens (ou de grupos de homens) sem que, necessariamente, se apele a argumentos que possam defendê-las racionalmente (Cullen, 1998: 26).

Embora a distinção técnica mais ampla seja mantida, outros pensadores a reelaboram, considerando-a, porém, interna a sua posição filosófica, indicando matizes que sublinham determinadas características teóricas particulares. Para não sobrecarregar o artigo, vou referir-me a autores conhecidos de nosso meio como Jürgen Habermas, John Rawls, sua crítica desenvolvida por Ronald Dworkin e a petite éthique de Paul Ricoeur.

A posição que Habermas expõe no "uso pragmático, ético e moral da razão prática” (Habermas, 2000: 109-126) não foi ultrapassada, pois se trata de uma "teoria discursiva da moral" (Habermas, 2000: 9); somente na disposição da terminologia aceita, a segue chamando "ética do discurso". Para explicar as denominações e ao conteúdo, ele inicia esclarecendo os diversos 
usos da razão prática, a partir de uma distinção entre questões pragmáticas (perguntas pelo adequado para alcançar um fim), éticas (atendem ao bom) e morais (delineamentos sobre o justo):

Conforme se delineie em cada ocasião ou problema, a pergunta "que devo fazer?" recebe um significado pragmático, ético ou moral. De todos os modos, trata-se de fundamentar decisões entre possibilidades de ação alternativas, embora as tarefas pragmáticas exigem outro tipo de ações, enquanto as tarefas éticas e morais e, as correspondentes perguntas, outro tipo de respostas (Habermas, 2000: 117).

O discurso pragmático está orientado para a recomendação de uma técnica apropriada ou de um programa realizável. Ao tratar-se, por outro lado, de uma decisão sobre valores que afeta a práxis vital, o correspondente discurso ético-existencial é um conselho em torno da correta orientação na vida. Com o ajuizamento moral das ações e máximas, ocorre um uso diferente:

Está o serviço de aclarar as legítimas expectativas de comportamento em vista de conflitos interpessoais que perturbam, devido a interesses contrapor esses, a convivência ordenada. Daí, trata-se de fundamentar e aplicar normas que estabeleçam os deveres e direitos recíprocos. O terminus ad quen do correspondente discurso moral-prático busca chegar a um entendimento mútuo sobre a solução correta de um conflito no campo do agir regulado por normas.

Como é possível perceber, em relação à moral propriamente dita, Habermas estabelece uma diferenciação entre a perspectiva interrogadora da primeira pessoa do singular e a do nós plural, que propriamente vai prevalecer nesse nível. Habermas expressa, com claridade, estas idéias no texto a seguir:

A formação individual da vontade segue, conforme a sua idéia própria, uma argumentação pública que, no foro interno, simplesmente se reproduz. Ali onde a moral topa com os limites da moralidade, não estamos diante uma mudança de 
perspectiva, da interioridade do pensamento monológico à publicidade do discurso, mas diante de uma modificação do delineamento do problema: o que se modifica é o papel no qual o outro sujeito nos sai ao encontro (Habermas, 2000: 117).

Na sua obra maior, Teoria da justiça, Rawls apresenta uma ética destinada a remover o utilitarismo dominante na tradição americana, substituindo-o por um construtivismo deontológico, propondo uma teoria política em defesa do Estado democrático liberal moderno. Segundo esses objetivos, ele esboça a definição do que denomina "teoria moral” em termos da tentativa de "descrever nossa capacidade moral”, a qual reduz a "teoria da justiça”, igualmente pensada como "descritiva de nosso sentido de justiça". Ele formula tais teorias como uma estrutura de princípios, que, ao modo de uma "gramática" do moral, devem presidir os juízos morais:

No melhor dos casos, o que se exige é uma formulação de um conjunto de princípios que, ao ser conjugados com nossas crenças e conhecimentos das circunstâncias, nos conduzem a formular esses juízos junto com as razões nas que se apóiam, se é que fossemos aplicar tais princípios de maneira consciente e inteligente (Rawls, 1979: 66).

Entre os críticos liberais de Rawls, R. Dworkin ${ }^{7}$ se destaca por sua fundamentação filosófico-moral do liberalismo (Dworkin, 1993: 101). Entendendo por "ética", de modo restrito, o estudo do que constitui o viver bem e seguindo a "estratégia de continuidade", Dworkin opõe-se à singular liberal da discontinuidade entre a perspectiva pessoal e a política (entre a filosofia política - a teoria da justiça - e a ética). Ele recorre à apresentação do contraste entre dois modelos formais antagônicos em torno do valor de uma boa vida: o modelo do "impacto", para o qual o valor de uma vida boa consiste em seu produto final, e o do "desafio", no qual se encontram as raízes éticas do liberalismo (Dworkin: 1993: 160); o valor de uma vida boa radica no valor inerente a um viver habilmente realizado (Dworkin: 1993: 111-112). Ele não

\footnotetext{
${ }_{7}^{7}$ Pensador proveniente da Filosofia do direito e considerado o filósofo público norte-americano mais importante.
} 
se opõe, mas reforça o vínculo entre vida boa e moralidade (justiça). ${ }^{8}$ Enfim, sendo formal, o modelo ético do desafio "não discrimina entre convicções éticas substantivas" (Dworkin, 1993: 190).

Embora as questões da ética tenha sido a preocupação constante na obra de P. Ricoeur, sua versão madura aparece sistematizada nos escritos dos anos 90. Os "estudos" sete, oito e nove de Soi-même comme un autre, apresentam a petite éthique, a qual o filósofo finalmente chegou. É possível reconhecer que nem a etimologia, nem a história impõem uma distinção no emprego dos termos e, por isso, a reflexão fenomenológico-hermenêutica do autor acata o nome técnico geral de "ética" para tal disciplina. Por outra parte, ele sustenta que, desde o princípio, é possível distinguir duas matizes: o que estimamos como bom e o que se nos impõe como obrigatório. A partir dessa distinção para o uso técnico demandado por seu teoria, Ricoeur outorga acepções diversas a cada um dos termos:

É, portanto, por convenção que devo reservar o termo ética para o objetivo [visée] de uma vida cumprida e o de moral para articulação deste objetivo em normas que, a sua vez, se caracterizam pela pretensão de universalidade e por um efeito constritivo (Ricoeur, 1990: 200).

Ao recorrer, assim, livremente às duas heranças, aristotélica e kantiana, Ricoeur procura destacar, na petite éthique, a primazia da ética sobre a moral, isto é, a necessidade que o enfoque ético tem do normativo e a legitimação do recurso prudencial ao enfoque ético quando a aplicação estrita da norma pode conduzir a situações práticas de estancamento ou impasse. Segundo esta hipótese, então, "a moral não constituiria mas a realização limitada, embora legítima e indispensável, do enfoque ético e, nesse sentido, a ética estaria abarcando a moral” (Ricoeur, 1990: 201).

Entre as questões mais importantes que as éticas filosóficas contemporâneas tratam, além de dilucidar a especificidade da disciplina, sua linguagem e seus modos argumentativos, assim como suas vinculações com o direito, as ciências sociais, outras ciências, etc., está a do agir moral, a partir dois delineamentos clássicos, mas, sobretudo, insistindo cada vez mais na centralidade

8 "Necessitamos parâmetros normativos que definam o objetivo de viver, e a justiça entra na ética quando perguntamos que recursos seriam adequados para que a gente compreendesse sua" (Dworkin, 1993: 151). 
de um conceito novedio de responsabilidade. Os dois autores emblemáticos para o tratamento dessa noção são: Emmanuel Levinas e Hans Jonas. Provenientes da tradição ética do judaísmo, assim como da fenomenologia e da hermenêutica, eles salientam o caráter inexorável da responsabilidade gerada a partir da extrema vulnerabilidade do outro ser vivo (Jonas), ou a partir da presença ineludível do rosto do outro (Levinas). Responsáveis e cativos do outro, todos os seres humanos estão obrigados a se encarregarem da vulnerabilidade do outro que, em razão dessa própria vulnerabilidade, se encontra frente a qualquer dever de reciprocidade. Para usar a expressão conhecida de Jonas, a responsabilidade seria "o dever do poder" (Jonas, 1995: 357); em Levinas, tal responsabilidade permanece compendiada no imperativo bíblico: “Não matarás” (Levinas, 1961, 1974, 1987, 1992). Por certo, na relação com esta problemática, está o tratamento das questões do sujeito moral, de sua autonomia e da construção da subjetividade e a identidade moral (Bonilla, 2004 e 2006), inquiridas também desde as óticas excêntricas e/ou descentradas da posição moderna de fundamento do sujeito, que visibilisam um "outro” não incluído nas tradições clássicas da ética. Entre elas, a enunciada por Levinas, que se acaba de mencionar, à que também poderiam acrescentar-se formas mais matizadas da ética discursiva (Benhabib, 1992, 2005, 2006) e as da filosofia intercultural, que tomam para si sujeitos em condições de marginação particular, como as minorias de gênero, imigrantes, grupos discriminados por proveniência étnica, etc. (Fornet-Betancourt, 2003 e 2004; Bonilla, 2006 e 2007; Waldenfels, 2006).

\section{A "ética aplicada" e 0 "giro ético" contemporâneo}

Nos parágrafos iniciais, afirmou-se que a renovação contemporânea das investigações em ética, em especial as filosóficas, é devedora também do surgimento e da consolidação da ética aplicada, um conjunto de disciplinas e práticas características de nosso tempo, apesar dos antecedentes históricos. A esse respeito, basta lembrar o exemplo de Aristóteles, que escreveu suas Éticas e sua Política para esclarecer as pessoas com competência na criação das leis do Estado (nomothétai). ${ }^{9}$ No período moderno, para lembrar um caso entre muitos, um pensador bastante desligado do público como Baruch Spinoza

\footnotetext{
${ }^{9}$ Esta tese ha sido defendida por R. Bodéüs (Bodéüs, 1982).
} 
referiu-se à causa dois irmãos De Witt e a absorveu teoricamente no seu Tratatus theologico-politicus de 1670.

Em termos gerais, as éticas do século XX abordaram seus objetos característicos de um modo tal que pouco incidiram nos assuntos práticos que foram aparecendo como conseqüência do desenvolvimento das ciências e da tecnologia ou da dinâmica própria da vida social. Uma demonstração: a ética material dos valores, com M. Scheler e N. Hartmann, inserindo o conceito de valor que as diversas axiologias tomaram da economia política, desenvolveuse à margem das teorias econômicas contemporâneas e da evolução de sua noção de valor. Embora a reputação de figuras como as de Jean-Paul Sartre e E. Levinas, observações análogas poderiam ser feitas a respeito das demais correntes da ética até quase o final da segunda parte do século passado. Esse diagnóstico é ainda mais evidente se pensarmos nos filósofos analíticos posteriores ao "giro lingüístico", que potenciaram a ruptura da tradição aos vínculos com a sociedade e seus problemas.

O redelineamento das questões essenciais das investigações da ética foi proporcionado pelos movimentos sociais anti-racistas, apelos de minorias étnicas, lingüísticas e sexuais, o auge do feminismo, etc., bem como de debates ocasionados por fatos de incidência mundial (De Marco, J. \& Fox, 1986: 11ss.). Além desses, salienta-se, os avanços da biotecnologia e da tecnologia médica, a percepção dos problemas ecológicos e ambientais, a consciência crescente dos aspectos moralmente conflitivos das atividades profissionais e de muitas outras instâncias da vida econômica, política e social. As exigências de um presente conflitivo foram não apenas o motor do pensamento filosófico, mas que trouxeram, ao mesmo tempo, modificações na docência e em diversas práticas de pesquisa, dando origem a instituições novas (comitês de ética em diversas instituições, inclusão de critérios éticos para a avaliação de projetos científicos, etc.).

O surgimento deste novo saber prático, caracterizado como interdisciplinar, dialógico e comprometido com o "mundo da vida", a tal ponto que se encarrega da profunda crise normativa e axiológica contemporânea, indica indubitavelmente um "giro global"10 na configuração dos saberes e das práticas. Trata-se de um verdadeiro "giro ético", presente no espaço cada vez maior assumido pelas pesquisas de "ética aplicada". O reconhecimento de responsabilidades que excedem o âmbito do conhecimento puro por parte dos

\footnotetext{
${ }^{10} \mathrm{~A}$ frase foi livremente tomada de Richard Rorty.
} 
cientistas, o aparecimento de novos modelos de ciência exigem valores e esclarecimentos e, inclusive, de orientação por parte da sociedade global. A denominação de "giro ético" sintetiza, no meu entender, a busca de um projeto de convivência novo, de outros costumes e hábitos de pensamento e de ação, de um lugar próprio (ethos) construído por todos os homens e para todos os homens, até mesmo os seres que habitam e habitarão este "planeta azul."11 As dúvidas relativas a esta busca - utópica, por certo - não estariam desvirtuando a ética. Em efeito, a questão está em saber se as éticas surgidas a posteriori, bem como a raiz dos conflitos que foram aludidos acima, possuem uma função crítica e construtiva real. A necessidade é saber se elas não passam de algo simplesmente tranqüilizador e, em decorrência, virtual, ou se já não é tarde para uma reação deste tipo. Tudo isso incita a uma reflexão contemporânea. ${ }^{12}$

A noção habitual de "ética aplicada", geralmente entendida como "a aplicação sistemática e prática de critérios ético-filosóficos às decisões humanas significativa”, se baseia em pressupostos que começam a ser vislumbrados na confusão gerada pela expressão "aplicada". Em sua primeira acepção, este é o infinitivo flexionado do verbo "aplicar", com o significado de "colocar uma coisa em contato com outra ou sobre outra”. Tanto para o caso do espanhol, como nas línguas romanas e no inglês, este verbo provém do verbo latino applicare, equivalente na época clássica a "abordar, dirigir-se a, apoiar" e, mais tardiamente, também a "acrescentar" (Ernout; Meillet, 1957: 514 s). Qualquer consideração demasiado rápida dessa etimologia pode conduzir à idéia errônea de que a "ética aplicada" seja mera "aplicação" (um procedimento mecânico) de princípios gerais, normas valores e/ou modelos de conduta já conhecidos, provenientes de alguma ética filosófica ou teológica a situações e casos específicos. Com essa descrição, um tanto irônica, pretendese ressaltar o caráter, muitas vezes, rotineiro e, por conseguinte, estéril, quando não ideológico e dogmático, de certas formas da ética aplicada de uso abrangente.

\footnotetext{
${ }^{11}$ A expressão "giro ético" empregada por mim, neste artigo, e em trabalhos citados não carece de antecedentes. O primeiro termo é um eco do emprego generalizado do termo "giro" (turn), sobretudo a partir dos anos 60 do século passado, para designar as mudanças mais importantes na marcha do pensamento contemporâneo (exemplos: giro lingüístico, giro pós-moderno, giro aplicado). Em segundo lugar, não se deve esquecer que o aparecimento desta expressão, em um contexto filosófico, é devido a Edmund Husserl, embora seja empregada despojada da perspectiva transcedentalista e fenomenológica na que foi, originariamente, formulada (Bonilla, 1998).

12 Cf. "Ética después" (Berbeglia, 1997).
} 
Para evitar este tipo de simplificações, o recurso mais eficaz, em primeira instância, foi, a meu parecer, a da mudança de denominação, apesar de esta tática haver provocado, em certo sentido, um aumento da confusão. Assim Peter Singer titula, de modo redundante, seu livro Pratical Ethics (1979), sem oferecer maiores esclarecimentos na definição que incorpora (Singer, 1993: 1). Ele também não discute as maneiras contemporâneas de entender este propósito, esboçando apenas uma lista de problemas práticos pertinentes. Para distinguir esta ética aplicada de outros ramos da ética, JeanLouis Baudouin, da Universidade de Montreal, a denominou "ética da situação" (McDonal et alii, 1988: 9), situando à ética aplicada na vertente escorregadia do situacionismo e do casuísmo. Para superar estas dificuldades, MarieHelène Parizeau optou por "ética setorial", cuja neutralidade exalta o âmbito concreto de pesquisa (McDonald et alii 8), embora o vínculo seja mais voltado ao aspecto "prescritivo", relacionado aos setores que distingue (bioética, Business Ethics e ética ambiental). Isso nada afirma acerca dos problemas epistemológicos, metodológicos e de fundamentação e/ou justificação mais substantivos. Eles são solapados ou, então, ocultados.

Heiner Hastedt propõe uma "ética orientada à aplicação", procurando superar as dificuldades da denominação Applied Ethics / Angewandte Ethik e defende, argumentativamente, a idéia de uma anwendugnsorientierte Ethik. Essa ética sustenta a possibilidade de uma reflexão prática sobre alternativas desejáveis do desenvolvimento tecnológico e procura reduzir a brecha tradicional entre ética filosófica e práxis. Sem apriorismo de princípios, nem respostas derivadas imediatamente da práxis, a ética orientada à aplicação deve conceder igual importância à reflexão ética fundamental e ao delineamento dos problemas práticos, ofertados em sua conexão mútua. Ele interpela, além do mais, a um trabalho interdisciplinar de índole particular e indispensável. Por isso, todas as pesquisas no campo da ética aplicada reafirmam essa necessidade. Em poucas palavras: Anwendungsorientierung significa que a filosofia tem uma orientação para a aplicação, embora a filosofia não se reduza, nem deve reduzir-se, à mera ocupação com as perguntas da aplicação (Hastedt, 1991).

Acima de tais discussões terminológicas, na prática acadêmica da pesquisa e, de modo especial, nos comitês de ética, mantém-se o nome de ética aplicada, popularizado a partir dos Estados Unidos. Por conseguinte, parece aconselhável o uso dessa denominação, embora em um sentido crítico e, no primeiro termo, dispondo de maior cuidado possível para aludir o risco 
epistemológico mais grave que ela resguarda. Trata-se de uma confusão, proveniente do campo da física, que distingue entre um "âmbito de princípios" e um "âmbito da aplicação". Se, no campo da física, há a distinção entre a física pura ou a teórica e a física aplicada ou a técnica, trasladando tais distinções ao domínio da ética, pareceria possível distinguir, da mesma maneira, entre o âmbito dos princípios constituído pelos princípios morais ou as teorias éticas gerais. Dessa forma, o aspecto de aplicação consistiria na aproximação destes princípios às situações e casos cuja conflitividade fosse evidente mediante o recurso a normas e regras de aplicação. ${ }^{13}$ Assim concebida, a aplicação da ética não estaria sempre necessitada da intervenção do âmbito filósofo. Por isso, ela poderia ser estandardizada. Além disso, tal ética aplicada serviria, de algum modo, de estímulo ao trabalho do pensador. Na verdade, uma vez fixados os princípios na forma considerada mais conveniente e extraídas as normas mais importantes, a aplicação propriamente dita poderia permanecer confiada a um "eticista", concebido como um técnico com a tarefa de propor regras de aplicação imediata e na resolução dos casos particulares.

Ao retomar as críticas de A. Leist, percebe-se que, desta forma, permanece liberado o passo a versões um tanto questionáveis da ética aplicada, como a refletida pelo "mantra" de Georgestown ou a tentativa eclética de T. L. Beauchamp e J. F. Childress, tal como eles o expõem no seu exitoso Principles of Biomedical Ethics (Beauchamp e Childress, 1979). Ironicamente, Leist lhes confere o nome genérico de "ética do livro de receitas", porque, ao deixar de lado as disputas fundamentais, eles apenas mostram os princípios em que tais teorias coincidem. Assim, eles justificam sua aplicação a casos particulares, sem tomar em conta a gramática própria de cada sistema, que transforma a concordância de princípios a algo meramente aparente. Em tais práticas, a pretendida interdisciplinaridade permaneceria reduzida a uma dificultosa síntese pluridisciplinar, estabelecida pela conjunção dos princípios - ético-filosóficos - e a apresentação do caso com o esclarecimento disciplinar do domínio correspondente - clínico, ambiental, farmacológico, ou outro, sem chegar à concreção interdisciplinar alguma.

Apesar destas críticas, é possível encontrar alguns traços positivos das pesquisas atuais mais frutíferas neste campo que, embora de modo parcial, de

\footnotetext{
${ }^{13}$ Nos últimos anos, surgiram modelos de ciência pós-normal, nos quais fica sensivelmente diminuída a diferença entre ciência pura e ciência aplicada. Estes modelos, ao incluírem também valores, não deixam de ser atrativos para o filósofo prático em seu estudo (Funtowicz, S.; Ravetz, 1994).
} 
acordo com as atividades nas que a ética aplicada se insere, também podem ser atribuídos às práticas de docência, comitês, consultoria, etc., relacionadas com a ética aplicada. Entre eles, pode-se destacar: a) o estabelecimento de um continuum teórico-prático; em outras palavras, a iluminação mútua do âmbito da teoria pelo da prática e vice-versa; b) o caráter "interdisciplinar" e não apenas multidisciplinar (mera conjunção de disciplinas), ao que procuram inclinar-se as pesquisas; ${ }^{14}$ c) a orientação "social”, ou seja, a ética aplicada se encaminha para o esclarecimento e a solução de problemas que se apresentam no seio da sociedade contemporânea; ${ }^{15}$ e d) o caráter "dialógico", por isso, muito mais que a adesão particular dos pesquisadores a alguma das variantes da ética, na maior parte das investigações se observa a preponderância metodológica das atuais intituladas "éticas do diálogo", denominação apta para designar a ampla gama de teorias de raiz intercultural, hermenêutica, liberal, discursiva, comunitarista, etc.

O destaque dos traços positivos da ética aplicada não significa uma minimização ou encobrimento das dificuldades e riscos que sua prática reúne: a) o problema dos critérios; b) os problemas de universalidade; c) o problema da especificidade das éticas setoriais; d) o problema das relações com a ética filosófica e com a filosofia prática.

A. Leist vislumbrou, com argúcia, o problema dos critérios, mostrando como, de fato, a onipresença da ética aplicada nas sociedades mais desenvolvidas (evidente, por exemplo, na profusão de éticas setoriais e profissionais) aceita o risco de sua trivialização teórica e prática. Ele propõe, então, os critérios de "relevância social" (que o problema afete ou possa afetar, de modo importante, à sociedade no seu conjunto ou a setores específicos) e de "claridade moral" (que os termos do problema envolvam conflitos de tipo tal em que se veja a pertinência de seu tratamento por parte da ética). A consideração de tais critérios resulta benéfica. Em primeiro lugar, porque indica um limite para as pesquisas e, em segundo, porque sua aplicação ao campo íntegro dos conflitos contemporâneos ajuda a determinar áreas temáticas de

\footnotetext{
${ }^{14}$ Para aclarar os conceitos de "multidisciplina" e "interdisciplina", de importância nas pesquisas sobre ética aplicada, se interpela à distinção efetuada pelo antropólogo Héctor Vázquez, segundo o qual, enquanto a primeira se refere a "justaposição de enfoques teóricos diferentes sobre os mesmos problemas, a partir de disciplinas distintas", a segunda implica "diferentes níveis de integração teóricometodológicos entre cada disciplina, mediante a construção de um denominador comum teórico nos dilemas delineados nas zonas fronteiriças intermediárias" (Vázquez, 1994, cap. 5).

${ }^{15}$ As três características, até agora mencionados, foram sistematizados por McDonald (McDonald, 1988: 10).
} 
interesse escassamente refletidas pelas investigações da ética tradicional que, em termos gerais sempre teve como marco de referência o agir temporal e espacialmente demarcado dos seres humanos adultos, normais e, em princípio, masculinos (casos "promédio"). Agora, haveria a possibilidade de sistematizar também as áreas pertinentes à ética aplicada a partir de casos "não promédio":

Os mais conhecidos itens da ética aplicada podem ser articulados nessa ordem: 1) Pergunta pelos direitos dos animais, os direitos morais da biosfera. 2) O problema do aborto, ajuizamento da medicina de reprodução, pesquisa em embriões. 3) Ética médica em geral. Problema do paternalismo, problema da eutanásia e de ajudas para morrir, profilaxias do suicídio. 4) Ética do meio ambiente, problema da fome no mundo, as gerações futuras, ameaça atômica. 5) Responsabilidade histórica, castigo justo (Leist, 1990: 58).

Sob o título dos problemas de "universalidade", circulam possíveis vinculações da ética aplicada, com discussões em torno de uma ética global. No parecer de diversos pensadores, que reivindicam mudanças radicais na ética, a fim de levar em conta as novas condições do agir, este aspecto da problemática é resultante da emergência contemporânea de questões globais, estendidas no espaço e no tempo, e da globalização das comunicações e do mercado. Também aparece a discussão acerca da possível adoção de princípios, normas ou imperativos de alcance universal (trata-se da universalização garantida pela via procedimental, de uma possível universalidade de contidos mais substantivos, ou da universalidade de horizonte da ética intercultural que parte dos contextos). Estes limites da ética aplicada tornam-se evidentes na distância entre as éticas predominantes no Ocidente e as do Extremo Oriente ou de outras latitudes. Em termos mais amplos, parece tratar-se da diferença entre um ethos individualista, antropocêntrico, centrado na autonomia da pessoa e ou respeito por sues direitos, e um ethos holístico, predominantemente biocêntrico (Sakamoto, 1996: 31-32). O caráter global dos problemas indica, claramente, a importância da discussão e a necessidade de encontrar possibilidades de harmonização entre perspectivas diversas, possibilidades que, talvez, devam ir além do caráter formal de um modelo argumen- 
tativo que, de forma duvidosa, pode ser compartilhado por todos os concernidos.

O problema está em saber se a "especificidade" das éticas setoriais, em sua variabilidade de horizonte temático, metodologias e práticas, não anula o próprio conceito de uma ética aplicada e impossibilita uma teoria geral da mesma. Além do mais, a questão é saber como a inter-relação entre as várias éticas setoriais pode ser resolvida se a teoria geral da ética aplicada pode ser vista como o espaço privilegiado para dilucidar as questões teóricas da própria aplicação e de sua metodologia geral e específica. Em terceiro lugar, o desafio é estabelecer uma relação necessária entre setores da ética aplicada, tais como a ética ambiental, a ética da economia, a ética das relações internacionais, etc., frente aos problemas complexos.

A discussão das "relações" da ética aplicada com a ética e a filosofia prática pode ser problematizada a partir de dois pontos de vista. No primeiro aspecto, os filósofos práticos se perguntam acerca da utilidade destas novas questões para o avanço real de seu labor. Contra os que sustentam a falta de interesse filosófico da ética aplicada, Leist, por exemplo, defende a opinião de que a ética aplicada, além de se ocupar com as questões que lhe são específicas, converteu-se em um campo de provas das teorias éticas. Do ângulo da interdisciplinaridade, pode-se pensar o problema com maior profundidade ainda. Por isso, a função da filosofia prática aparece como mais ampla que a do mero controle metodológico. Além das necessidades fácticas, no trabalho do filósofo prático, a interdisciplinaridade aparece como uma relação necessária e estrutural, imposta pela constituição do campo problemático e pelo caráter dos atores envolvidos, então, para o caso particular da ética aplicada, tal interdisciplinaridade pode ser pensada a partir da própria ética. Além do mais, pode-se ampliar, de modo insuspeitado, o campo prático, dando lugar a atores até agora silenciados, de forma a contribuir na construção do saber prático a partir de seus próprios saberes e suas próprias experiências, democratizando, de modo definitivo, o campo da ética, antes reservado a especialistas (Bonilla, 2006b). 


\section{Referências Bibliográficas}

ARANGUREN, J. Ética. 4 ed., Madrid: Revista de Occidente, 1968.

ARISTÓTELES. Política. Madrid: Centro de estudios políticos y constitucionales, 1997.

BEAUCHAMP, T. L.; Childress, J. F. Principles of Biomedical Ethics. New York: Oxford University Press, 1979.

BENEDICT, R. El crisantemo y la espada. Madrid: Alianza, 1974.

BENHABIB, S. Situating the Self. New Cork: Routledge, 1992.

. Los derechos de los otros. Extranjeros, residentes y ciudadanos. Barcelona:

Gedisa, 2004.

Las reivindicaciones de la cultura. Igualdad y diversidad en la era global. Buenos Aires: Katz, 2006.

BERBEGLIA, C. E. "Ética después". In: Bianco, Gabriella (Coord.). El campo de la ética. Buenos Aires: EDICIAL, 1997.

BIANCO, G. (Coord.). El campo de la ética. Buenos Aires: EDICIAL, 1997.

BILBENY, N. Aproximación a la ética. Barcelona: Ariel, 1992.

BODÉÜS, R. Le philosophe et la cité. Recherches sur les rapports entre morale et politique dans la pensée d'Aristote. Paris: Les Belles Lettres, 1982.

BONILLA, A. B. "El giro ético contemporáneo". In: Bianco, Gabriella (Coord.). El campo de la ética. Mediación, discurso y práctica. Buenos Aires: Edicial, 1997.

. "Eurídice y Orfeo 'ohne Eigenschaften”. In: Bauzá, Hugo (Comp.). El imaginario en el mito clásico. IV Jornada organizada por el Centro de Estudios del Imaginario". Buenos Aires: Academia Nacional de Ciencias de Buenos Aires, 2004.

"¿Quién es el sujeto de la bioética? Reflexiones sobre la vulnerabilidad”. In: Losoviz, A. I.; Vidal, D. A.; Bonilla, A. B. Bioética y Salud Mental. Buenos Aires: Akadia, 2006.

"Autonomía moral entre limones y colectivos: la construcción identitaria de las 'mamacitas' bolivianas en Buenos Aires". In: Wehr, I. (Ed.). Un continente en movimiento. Migraciones en América Latina. Frankfurt a. M./Madrid: Vervuert/Iberoamericana, 2006b.

. "Ética, mundo de la vida y migración". In: Salas Astrain, Ricardo (editor). Sociedad y mundo de la vida. Santiago (Chile): Ediciones Universidad Católica Silva Henríquez, 2007. 
CAMPS, V.; Guariglia, O.; Salmerón, F. Concepciones de la ética. Madrid: Trotta, 1992.

CANTO-SPERBER, M. (Dr.). Dictionnaire d'éthique et de philosophie morale. Paris: PUF, 1996.

CUlLEN, C. A. "El debate ético contemporáneo". In: Enoikos, 13, Buenos Aires, 1998.

DE MARCO, J.; FOX, R. M. New Directions in Ethics. The Challenge of Applied Ethics. New York/London: Routledge \& Kegan, 1986.

DIOGENES LAÉRCIO. Lives of Eminent Philosophers. London/Cambridge: W. Heinemann, Harvard University Press, 1959, 2 vol.

DODDS, E. R. Los griegos y lo irracional. Madrid: Revista de Occidente, 1960.

DWORKIN, R. Ética privada e igualitarismo político. Barcelona: Paidós I.C.E./U.A.B, 1993.

ERNOUT, A.; MEILLET, A. Dictionnaire étymologique de la langue latine. Histoire des mots. 4 ed., Paris: Klincksieck, 1959.

ESTERMANN, J. Filosofía Andina. Estudio intercultural de la sabiduría autóctona andina. Quito: Abya-Yala, 1998.

FORNET-BETANCOURT, R. (Hrg.). Diskursethik oder Befreiungsethik? Aachen: Verlag der Augustinus-Buchhandlung, 1992.

. Modelle befreiender Theorie in der europäischen Philosophiegeschichte. Ein Lehrbuch. Frankfurt a. M: IKO, 2002.

Interculturalidad y filosofía en América Latina. Aachen: Wissenschaftverlag Mainz, 2003.

Interculturality, Gender and Education. Frankfurt a. M.: IKO, 2004.

Funtowicz, S.; Ravetz, J. Epistemología política. Ciencia con la gente. Buenos Aires: CEAL, 1994.

HABERMAS, J. Aclaraciones a la ética del discurso. Madrid: Trotta, 2000.

HASTEDT, H. Aufklärung und Technik. Frankfurt a. M.: Suhrkamp, 1991.

HEGEL, G. W. F. Principios de la Filosofía del Derecho o Derecho Natural y Ciencia Política. Buenos Aires: Sudamericana, 1975.

JONAS, H. El principio de responsabilidad. Barcelona: Herder, 1995.

LEIST, A. “¿Qué es la ética aplicada?”. In: Cuadernos de ética, 10, 1990.

LÉVINAS, E. Humanismo del otro hombre. Buenos Aires: Siglo XXI, 1974.

. De otro modo que ser o más allá de la esencia. Salamanca: Sígueme, 1987. . Totalité et infini. Essai sur l'exteriorité. La Haye: Nijhoff, 1961. . Entre nosotros. Valencia: Pretextos, 1992. 
LUHMANN, N. Sistemas sociales: Lineamientos para una teoría general. Barcelona: Anthropos, 1998.

MCDONALD, M. et alii. Toward a Canadian Research Strategy for Applied Ethics. Ottawa: Canadian Federation for the Humanities, 1988.

PLATTS, M. Dilemas éticos. México: FCE, 1997.

PONS, A. "Moeurs". In: Canto-Sperber, M. (Dr.). Dictionnaire d'éthique et de philosophie morale. Paris: PUF, 1996.

RAWLS, J. Teoría de la justicia. México: FCE, 1979.

Real Academia Española. Diccionario de la lengua española, 21 ed., Madrid: EspasaCalpe, 2000.

RICOEUR, P. Soi-même comme un autre. Paris: Du Seuil, 1990.

SAKAMOTO, H. "Foundations of East Asian Bioethics". In: Eubios Journal of Asian and International Bioethics, 1996,vol. 6 (2).

SINGER, P. Practical Ethics. 2 ed., New York: Cambridge University Press, 1993.

VÁZQUEZ, H. La investigación sociocultural. Crítica de la razón teórica y de la razón instrumental. Buenos Aires: Biblos, 1994.

WALDENFELS, B. Grundmotive einer Phänomenologie des Fremden. Frankfurt: Suhrkamp, 2006.

E-mail: abonilla@sion.com

Recebido: 06/2008

Aprovado: 11/08 